\title{
Feminist Critiques against Traditional Approaches to Security
}

\author{
Petrus K. Farneubun \\ Jurusan Hubungan Internasional, FISIP Universitas Cendrawasih, \\ Jayapura
}

\begin{abstract}
Feminists claim that national security is a model of masculinity domination, which hardly disputes. This essay addresses feminists critique on notion of conventional security and provides feminists own definition. It shows that feminists adopt comprehensive approach in relation to security. They tend to define security in a broad term to accomodate contemporary issues. They also propose neutral concept of security to demonstrate that security is not exclusively men's business.
\end{abstract}

Keuwords: Feminism, security, national security, hegemonic masculinity.

Kaum feminis mengklaim konsep keamanan nasional sebagai konsep yang bias laki-laki dan dikonstruksikan untuk merayakan kebesaran maskulinitas. Klaim feminis ini sulit dibantah dengan melihat fakta bahwa sebagaian besar negara masih mempercayakan pengamanan negara kepada laki-laki. Tulisan mengangkat kritik feminis terhadap konsep keamanan tradisional dan menyuguhkan pandangan feminis yang mengadopsi pendekatan keamanan komprehensif. Feminis cenderung mendefinisikan keamanan secara luas guna mencakup isu-isu keamanan kontemporer. Feminis juga menawarkan konsep keamanan yang netral untuk menunjukan bahwa keamanan bukan sematamata tanggung jawab laki-laki tetapi juga perempuan.

Kata-Kata Kunci: Feminisme, Keamanan, Keamanan Nasional, Kebesaran Maskulinitas 
The concept of security has been a topic of debate. Scholars formulate the concept of security based on their theoritical traditions and their definitions tend to be very specific. Realists, for example, perceive security in the realm of state security and military threat. And yet, as new threats and actors emerge, various definitions and expansions have been made. This indicates a common acceptance that security is a contested concept (William 2008, 1); ambigous symbol without any precise meaning (Wolfers in Buzan 1983, 4); or underdeveloped concept (Buzan, 1983, 3); complex and contested notion - heavily laden with emotion and deeply held values (Kolodziej, 2005, 1). Thus, defining security is a problematic because it is always tied to a particular referent object, to internal/external locations, to one or more sectors and to a particular way of thinking about politics (Buzan and Hansen, 2009, 10). Meanwhile, feminists in Indonesia understand security as free from violence or free from physical and sexual threats which are mostly perpetrated by men. Violence against women appears to be one of the most serious issues in Indonesia nowadays. Data from The National Commission on Violence against Women, for example, shows an increase of physical and sexual violence against women every year (Komnas HAM 2014).

Although the traditionally defined security remains dominant, it does not mean it goes unchallenged. Critical theorists raise serious challenge to the traditional concept of security claiming that the concept is obsolete. They believe that traditional concept is not only too narrow and fails to address urgent security problems such as global warming, HIV/AIDS, rape and poverty, but also fails to include emerging new global actors in addition to states. In traditional understanding, security is defined under realism framework which defines security in political and military terms and focuses on state's use of force to counter potential external threats. In this context, security is viewed in relation to wars and threats among great powers. Therefore, external threats are restricted to military threat and the only actor responding to the threat is the state.

But defending state from external threats certainly requires strong military power. Under realism framework, superiority in military power is ultimately important as it will deter any possible attack and keep the state and people safe. This apparoach places national security as the main referent. Power is considered as driving force to keep state's interest and primary end of political action.

Furthermore, the concept of security has many facets. In political discourse, we might find security fragmentation. National security, international security, human security and military security are among the few of the fragmentations. These notions of security develop over 
time. Buzan,Waever and Wilde for example suggested that security should be analysed in five different 'sectors' of society: military, political, economic, societal and environmental sectors (Buzan et al 1998,8).

Meanwhile, Rothschild focuses on changing of security forms. He argues that the extention of security takes four main forms: first, extention from nations to individuals (downwards extention); second, extention from security of nations to the security of the international system (upwards extention); third, security is extended from military to political, economic, social, environmental, or "human" security (Horizontal extention); fourth extention on political responsibility for ensuring security from national states, international institutions downwards to regional or local government, sideways to nongovernmental organizations, to public opinion and the press, and to the abstract forces of nature ( Rothschild 1995, 55).

Although the concept has been extended both in the terms of the meaning, analysis of actors and sectors, it still dissatisfies many people. Feminists are perhaps the most outspoken critics of the notion of security. Calling to end discriminatory practices against women, feminists have criticized the conventional concept of security as they believe such concept not only narrowly constructed but also more male oriented. In addition, feminists criticize the structure of government and global politics which are organized in male-dominated lines and neglect feminist perspectives. As a result the voices of women are often unheard.

Nevertheless, in the contemporary global politics and international relation, there has been dramatic change in the understanding of gendering global politics. Women roles have been extended. These changes have been perceived as the outcomes of a long struggle initiated by women. The first feminist movement started in England in the late $19^{\text {th }}$ century was the leading force to break a deep-seated patriarchal tradition which limited roles of women in society.

It is a significant outcome that since the end of cold war, feminist perspectives on world politics including security have been increasingly recognised. The recognition becomes obvious after the UN passed a number of key resolutions to mainstream gender perspectives in all fields. Security Council Resolution 1325 adopted on 31 October 2000, for example, urges member states to increase women's participation in peace process and security decision making. The first article of the resolution uses strong language urging member states to ensure increased representation of women at all decisions making levels in regional, national and international institutions and mechanisms for the prevention, management, and resolution of conflict. The adoption of the 
resolution and its passage is a result of the pressure by women activists to accomodate women voices in the field of peace and security.

Despite calling for full and effective implementation on the resolution, many member states, in practice, have not involved women from security decision making. Security is still considered as male business. As a result, women perspective on security still does not get much attention and the domination of conventional concept of security remains strong. With this respect, this essay addresses three key related issues within feminists' literatures. It begins by addressing feminists perspectives on the roots of man supremacy over women. Knowing the roots is important as it will give background on women perspective's about their long-lasted and hard-to-change subordination status. It then goes on to examine feminists' critique on the notion of security. The final section presents feminists' alternative notion of security. This paper demonstrates that although traditional understanding of security and dominant role of men in military service still prevail, the contribution of feminists to provide broader insights on security issues and foster an equal role-sharing in decision making policy has somehow been successful.

\section{Women on the Peripheries of Power}

The role of women in global politics are often undermined. Women are perceived as complementary to men both in their status and in their perception of the world. Men make decisions, construct social reality and women subscribe to it. It is true as Tickner points out that although women has played key roles in global politics, they are still on the peripheries of power and this has been evident not only in the level of the state level but also in international system level (Tickner 2001, 2).

This exclusion is a wake-up call for feminists to bring women to the equal position along with the men in the international arena. Introducing a new approach to international relations which takes gender as analytical tool makes an enormous impact and considered successful. As a matter of fact, feminism has been included as one of the central critical theories in the theories of international relations challenging traditional theories of realism and liberalism. Critical theorists attempt to draw a sharp dividing line between traditional theories and contemporary critical theories. Moreover, critical theorists seek to develop more comprehensive approach to international security with among its core tenet is emancipation. Shapcott (2010) argues that "for contemporary critical theorists, emancipation means both freedom from unnecessary suffering and freedom to partake in dialogue, consent, and deliberation concerning matters that affect everybody (Shapcott in 
Reus-Smit and Snidal 2010, 328). Feminists try to emancipate women from men's exclusiveness and promote women equal participation.

It is clear that there is a conflict between traditional understanding and contemporary understanding of security. The approach of feminists are certainly twofold. In the first place, feminists attack the traditional theories making them irrelevant and inadequate in responding the the contemporary reality. Secondly, feminists accentuate the issue of women insecurities under new theoritical framework called feminism. According to some feminists scholars, feminism entered the discipline of International Relations (IR) at the end of the 1980s, about the same time as the "third debate," or the beginning of what has been called a "postpositivist era to challenge the conventional ontological and epistemological focus of the field the international relations (Tickner in Ackerly et al 2006, 19; Tickner and Sjoberg in Dunne, Kurki and Smith, 2010, 196; Jacqui True in Burchill et al 2005, 215; Sylvester 2004, 8-9). Literatures about gender issues, women and politics and feminists critiques on the methodologies of international relations began to flood.

Since the feminists' effort gain momentum and as they have gained greater legal rights, freedom of expressions and have influenced most field of political science, their role in peace and security activities are recognized under international organizations. A clear example showing such recognition is the adoption of United Nations Security Council Resolution 1325 on 31 October 2000 to include women in peace and security activities. UN Secretary -General report 2004 shows that since the adoption of the resolution, women participation in peace and security missions have increased- having involved in numerous peace procesess, peacekeeping operations, humanitarian response, postconflict reconstruction, disarmament, demobilization and reintegration.

Although feminist have gained access to peace and security initiatives in international level, they are still dissatisfied with how states and international organzations defines and construct security. Therefore, the notion of security is called into questions. In other words, they believe that the notion of security still blankets with what Connell calls 'hegemonic masculinity.' Connell introduced this concept to indicate male superiority and subordination of women which is structured in patriarchy system or ideology of supremacy. Connell $(1995,77 ; 2005,77)$ defines "hegemonic masculinity as "configuration of gender practice which embodies the currently accepted answer to the problem of the legitimacy of patriachy, which guarantees (or is taken to guarantee) the dominant position of men and the subordination of women." Sandra Via also advanced the definition of Kronsell and Tickner that "Hegemonic masculinity refers to certain masculine norms and values that have become dominant in specific institutions of social control and remain in 
those institutions to maintain patriarchal social and political orders (Sandra Via, 2010 in Sjoberg and Via 2010, 43).

Similarly, in the discussion paper of Feminist Institute of the Heinrich Boll Foundation, it says, 'typical of hegemonic masculinity is the exclusion and subordination of women as well as the possession of arms and the exercise of violence to safeguard male dominance (Feminist Institute of the Heinrich Ball Foundation 2006, 69).

Using Connell's concept is helpful to address the concern of women. This concept has influenced gender studies and has become feminists' popular vocabulary over the years. Its popularity is evident. For example, Connell and Messerschmidt points out that the term 'hegemonic masculinity' has been used by more than 200 papers (Connell and Messerschmidt 2005, 830).

The hegemonic masculinity is visible in international relations and military areas. In these areas, women play very minor role and the exclusion of women remains unchanged. Tickner (in Adam Jones 2006, 408) points out, 'international politics is such as thoroughly masculinized sphere of activity that women' voices are considered inauthentic ... The values and assumptions that drive our contemporary international system are intrinsically related to concepts of masculinity...'

The hegemonic masculinity is deeply preserved in many different ways. However, there are two general propositions that feminists bring up as the roots of hegemonic masculinity-constructed legal structure accounted by liberal feminists and patriarchal system argued by radical feminists. Participation in public life was the key to advancing the status of women (Steans 2010, 157). Yet, liberal feminists attempt to address the issue of women exclusion of women from political spheres. They argue that women subordination can be diminished by removal legal barriers and other obstacles that have denied their rights and opportunities as men. Also, by incorporating women into existing institutional structure on equal basis with men, women will be able to exercise their full potential (Tickner 2001, 10-11). Thus, the underlining argument of the liberal feminists is that legal structure is constructed in such a way by male hierarchy to prevent women from getting in. This means that liberal feminism raises concern over the issue of women underrepresentation in decision making politics and promote equality among both men and women (Whitworth 2008 in William 2008, 105; Peou 2010, 202)

On the other hand, radical feminists believe that women' 'oppression' was too deep to be eliminated by the removal of legal barriers. They 
claim that women were oppressed simply because of patriarchy system of male dominance or constructed under the very norms of masculinity (Tickner 2001, 11; Whitworth 2008 in William 2008, 105). Responding to the patriarchal system, Enloe $(2004,4)$ points out:

\begin{abstract}
"Patriarchy is the structural and ideological system that perpetuates the privileging of masculinity. All kinds of social systems and institutions can become patriarchal. Whole cultures can become patriarchal. That is a reality that has inspired feminist movements to become national in scope, mobilizing energies on so many levels simultaneously....patriarchal system are notable for marginalizing the feminine.”
\end{abstract}

Given these liberal and radical feminists point of view, it is clear that while there are significant differences between them, both hold similar view that women subordinations are structurally constructed. Therefore, the key concern for the feminist theory is to explain such subordination as such inequality is primary impediment to women's security. In addition, it becomes a mandatory undertaking for feminists to remove the barriers in order to promote gender equality and emancipation.

Removing the barriers, however, is not an easy task for feminists. Political strategies have been advocated by feminists and to some extents there have been positive outcomes. For example, over the last ten years, a dramatic change has been made in international relation and security fields. There has been substantial recognition of feminist's approaches in foreign policy and the inclusion of the approaches in the security discourses. Despite the recognition of the feminists' approaches, feminists have never been satisfied. The question then is: why do women still feel dissatisfied and their voice unheard? There are at least two basic reasons that can be offered. First, feminists, mostly liberal feminists and feminist empiricism, dissatisfy with the fact that there is still imbalance of men and women representatives in the decision making bodies which mostly make their voice unheard and remain in the peripheries of power. Feminists try to back up their claim by providing substantial evidence for the issue of subordination. Global Gender Gap Report 2013 published by World Economic Forum, for example, shows low proportion of women in parliament, government ministerial level, upper house or senate and executive council worldwide in which within these bodies decisions are made. It concludes that no country in the world has achieved gender equality.

Similarly, Inter Parliament Union (IPU) gives the figures of women representation in parliament in 2012 is only 20.3 percent slightly increased from 19.5 in 2011 (IPU, 2012 Report). European Union also confirms the under representation of women in power spheres. In the foreword to the EU's report, Vladimir Spidla, member of the EU for 
Employment, Social Employment and Equal Opportunities, acknowledges, '...even if European Union's efforts to increase women's participation in decision making have been consistent and certain progress has been achieved, women are still under-represented under all spheres of power in most Member States and in the EU Institutions (European Commission, 2008). Moreover, the composition of women in US foreign service also shows a lower number compared to men's. Rossati and Scott pointed out, "More women and minorities have gained entry to the foreign service in the last few decades, but they remain completely underrepresented in comparison to their numbers in society (Rossaty and Scott 2011, 146). They further claimed that the foreign service is "a very exclusively old boy network" (Rossaty and Scott 2011, 144). This imbalance certainly has an impact on women. Both liberal feminists and feminist empiricism call for 'bringing women in.' According to them, 'the absence or under representation of women in position of power and influence is itself a major obstacle to pushing women's interests and concerns onto the agenda of international politics (Steans 1998, 161). Second, feminists still dissatisfy and question the long-preserved conventional concept of security which in Elshtain's term 'ontologically suspicious concept.' Feminists agree that conventional concept of security secure sovereignty of man and neglect the genuine security of human beings. Moreover, the long-established conventional concepts of security are narrowly constructed.

\section{Feminists Critique on the Notion of Security}

Elise Boulding in his study found that women researchers agree that the concept of security must be redefined but the problem is no agreement on the content of a new concept of security could be found (In Inger Skjelbaek in PRIO Report, 29). Although feminists have very different definitions of security, explanations of insecurities and no agreement about the content of a new concept of security, feminists agree that the notion of security has failed to mainstream women perspectives. Feminists claim that the notion of security still favors men's interest over women's interests and most often women's voice does get much attention. Tickner $(2001,37)$ points out that '...women have been writing about security from a variety of perspectives for a long time; their voices, however, have rarely been heard....'

To help us better understand feminists critique on the notion of security which is narrowly constructed, and therefore it is reasonable to suspect its content, I will spefically use the concept of national security to explain how security is built on men's supremacy. This choice is deliberately made due to the fact that national security or national interests is the core value of a state in its relations to other states. 
National security has been criticized by many feminists. According to feminists this concept is male-biased term. Eric Blanchard $(2003,1289)$ for example, illustrates that "national security discourses are typically part of the elite world of masculine high politics." Similarly, Tickner (2001, 263) points out, 'state' national security policies are often legitimated in terms of masculine characteristic.' David Baldwin and Helen Milner (1999) claim further, 'the concept of national security is one of the most ambiguous and valued-laden terms in social science (Terrif 1999, 1).

The critics' views on the concept of national security are politically correct for two reasons. In the first part, when we trace back the birth of the concept, particularly modern concept of 'national security, developed by US, it is obvious that the concept is part of 'celebration of masculinity.' National security is a new concept as it replaced 'Common Defense' in 1947. According to Yergin (2006) the doctrine of national security developed to explain America's relationship to the rest of the world (Neocleos 2006, 364). Furthermore, according to Buzan and Hansen $(2009,12)$ national security was "developed in a political climate where the United States, and theWest more broadly, understood themselves as threatened by a hostile opponent."

The concept itself emerged after US President Harry S. Truman asked for the creation of a unified military establishment in 1945 and followed by the advocating of 'Council of Common Defence' in 1946 by both the USA army and the USA Navy (Neocleos 2006, 363). These two USA military forces in fact were mostly filled by men and the restriction to women were enormous. For example, a year after National Security was introduced, President Truman signed Armed Services Integration Act on 12 June 1948. This law set up statutory restriction that limited women to no more than two percent of total force strength and women officers were not permitted to hold a rank higher than the grade of colonel (Murnane 2007, 1066; Burrelli 2013). This limit then was repealed in 1967 (Burrelli 2013, 1). The exclusion of women is also very evident in Indonesia armed forces. According to Parawansa, "there are very few high-ranking women in military" and this is because of patriachal values (Parawansa in Robinson and Bessel 2002, 73). Data from Indonesia Ministry of Defense and Security 2012 confirm this fenomenon: 9 men and 1 woman for level 1 rank (eselon 1); and 60 men and 1 women for eselon 2 (Kemhan 2012). This figure illustrates that the security of the states rest on men capacity.

Another reason 'national security' is a 'suspicious concept and narrowly constructed' because it is an exclusive term or a state-centric. It is a typical concept of realism. It is an exclusive concept as it focuses on one's 
internal security or state survival. According to Nicole Ball, the term internal security is a "misnomer since its purpose is rarely to make all citizens equally secure but rather to enable ruling elites to remain on power, often at the expense of the majority of the population" (Tickner 2001, 41). Feminists criticize this concept as it places state as main referent object. Different from this concept, feminists take humanistic approach or bottom-up approach focusing not on state but referents objects are beyond state, such as individual security and global security.

In addition, national security is a construct concept of 'defending one's own country and against the others. For example, Bush declared war on terror and war in Iraq and Afghanistan to defend American national security and secure American lives. US National Security Strategy issued in September 2002 lays down the principle of protecting American people and American interest as 'the first duty of the United States government (US National Securuty Strategy, 2002; 2006). To succeed the principle, Department of Homeland Security was established adding the two previous-established key national security institutions; Department of Defense and Intelligence Community. According to the National Security Strategy document, the Department of Homeland Security focuses on three national security priorities: 'preventing terrorist attacks within the United States; reducing America's vulnerability to terrorism; and minimizing the damage and facilitating the recovery from attacks that do occur (US National Securuty Strategy, 2002; 2006).

The main emphasize of the national security is the primacy of military hardware to protect states or nation interests from external threat in which it is preserved as men's tasks. Peterson argues that 'militarism is a celebration of masculinity (in Skjelbaek, 42). Excessive emphasis on military hardware has been criticized by feminists and military scholars. For example, Robert McNamara (1968) points out, 'in a modernizing society security is not a military hardware, though it may include it; security is not military force though it may involve it; security is not traditional military activity though it may encompass it. Security is development and without development there can be no security (McNamara 1968, 149).

McNamara concept of securirty as development is attractive because conventional security framework does not address this issue and there is a similarity to the feminists' proposal of security.

Agreeing with McNamara concept, feminists try to expand the concept of security to address economic inequality and injustice, marginalized population and the growing feminization of poverty which mostly hit the women. In this sense, feminists question the notion of human security as they see that boys' and men's security is prioritized over that of girls and 
women because of sexism. Gender based victimization is rooted and built into the cultural and patriachal system which perceive women as the ones who need protection and life sustainment.

Furthermore, it is obvious that securing national interest and to 'against the others' requires not only advanced military hardware but also warstrong and skillful individuals and men are primarily chosen to fill this position. In combat, for example, women are excluded. The exclusion of women from combat is a result of the influence of essentialists' stereotypes. In essentialist's view women are perceived as naturally weak, nurturing, passive and peace-loving. The ascribed women natural characteristic is not compatible with the military world which is full of violence and aggressiveness. The notion of essentialism is rejected by feminists because its notion of powerless women. Tickner (2001) points out, 'certain feminists are cautioning against the association of women with peace, a position that, they believe disempowers both women and peace (Tickner 2001, 6). Moreover, some feminists argue that ascribing women as weak and peaceful is constructed to preserve the patriarchal state and justify women's vulnerability who is in need of protection. This is clearly seen in the "myth of 'protection or the notion of male warrior (warrior hero) who protects women and children preserved as most vulnerable. Women are seen as 'beautiful soul." This notion 'men protect women' in fact, has been challenged as both men and women are victims of war and conflicts.

In addition, feminists criticize the notion of essentialism because it conceptualizes qualities of an object as timeless and immutable (static entity) and the nature of women as weak creatures is fixed. Skjelbaek, for example, illustrates the problem of essentialism. She states, ...'the main problem with the essentialists position is...it does not follow for change. It holds that we remain essentially the same people throughout life (Skjelbaek, 25).

It can be argued that security and military policy is the product of the essentialism influence as the exclusion of women is obvious. As a matter of fact, many countries have very low presence of women in military and security decision making. In an interview with Washington Post, the then President of USA, George W. Bush, makes it clear that under 1994 Pentagon policy women should be excluded from direct combat brigades, such as infantry or armor. The president Bush says, 'there's no change of policy as far as I'm concerned. No women in combat. Having said that, let me explain, we've got to make sure we define combat properly: We've got women flying choppers and women flying fighters, which I'm perfectly content with" (Washington Time, 2005). Interestingly, the restriction is lifted in 2013 and according to US Department of Defence, at present women make 15 percent or nearly 
202-400, of the U.S. military's 1.4 million active personnel (Department of Defence 2013). This reflects an increasing recognition of women military capacity. The 19994 Pentagon policy and Bush statement, certainly, represent the policy of other countries in regard to the involvement of women in military. Most still believe that women lack fighting capabilities and physical strength, neccessary skills for in the battleground. For example, British military policy still bans women fighting on the front line. According to ex-colonel Richard Kemp, women serving in the infantry would diminish the army's 'warrior ethos' (the Huffington Post 2014). He further said, “ A killer instinct and aggression is more of a male characteristic..." (the Huffington Post 2014). Similarly, according to Indonesia miliary spokesperman, Sagom Tamboen said, "women are not set to go to war. Men are more ready than they are" (The Jakarta Globe 2010).

This exclusion, automatically, keeps women staying on their traditional roles, engaging in nursing, communication and clerical duties. In other words, the essentialists stereotyping make women fit for certain responsibilities and unfit for the others. This policy would like to suggest that military and security are not women world as it requires hard-power specialties and this can only be applicable to men. Cynthia Enloe (1983) nicely illustrates this condition, 'the military, even more than patriarchal institutions, is a male preserve, run by men and for men according to masculine ideas and relying on man power. The military has been presented to women as inaccessible, a secret order that does not need women (except as sweethearts, pin-ups or prostitute) (Weinstein and Christie 1997, xiii). The conception of women social roles here is strongly constructed and formalised within insitutional system and policy so that women understand the boundaries and scope of their relation to military spheres.

\section{Feminist Concept of Security}

Criticizing the traditional theoritical deficiencies and the realist's concept of security as male-based concept which primarily emphasize military hardware and protection of state' power, feminists propose different notions of securitity. Different perspectives have emerged as there has not been consensus among feminists on the notion of security. This divergence, however, should not be seen as an inconsistency of thought but rather a way to see the same problem from different angle or from different background of experience. As Whiworth has point out that the notion of security among women are diverse because feminists apply different perspectives and theoritical framework to analyse the issue of peace and security, issue of gender and world problems (Whitworth 2008 in William 2008, 105). Similarly, Peo (2010) argues 
that feminism is built upon various traditions: essentialist, liberal, cultural or radical, socialist (Marxism, Leninism, and Maoism), postcolonial, and postmodern (Peou 2010, 199); therefore Steans rightly says that "feminism is not a monolithic body of thought" (Stean et al 2010, 155). Although there has not been a common notion of security among feminists groups, it is fair to say that feminists are all involved in the consideration of fundamental problems of traditional construction of security and propose different notions. First, feminists propose neutral concepts of security. Feminists believe that security is not exclusively men's business but also women's. In this way, women also feel responsible to promote security and to contribute their expertise and thought for the advancement of the security system. Tickner, for example, has attempted to suggest a new neutral concept. She proposes global or ecological security to replace conventional and male-biased concept. According to Tickner, "these terms do not indicate specific gender orientation, but are based on values which are from those underlying the conventional definitions. The strength of this approach is also that both men and women can be practitioners of this line of thinking (Skjelbaek, 36).

In addition, neutral concept suggests that security is not individual or the task of a nation to carry on but everyone's task. It is collective security that requires multilateral commitment. Therefore, global cooperation to share global challenge is essential. Palme Commission calls for global cooperation in its neutral concept of 'common security.' It says, 'nations must begin to organize their security policies in cooperation with another. Common Security is therefore based on the idea that increases in one's own security can not be attained by provoking insecurity in others (Booth in Booth 1991, 344). This concept got support in the 1980 s by many policymakers and academics mostly outside the US.

Second, feminists proposes a broader notion of security. Tickner and Sjoberg point out that feminists "not only broaden what security means but also who is guaranteed security" (Tickner and Sjoberg in Dunne, Kurki and Smith eds, 204). They define security to include physical, structural and ecological violence (Tickner and Sjoberg in Dunne, Kurki and Smith eds. 203-204). Accordingly, Reardon proposes a broad notion of security to include four main components: sustainability, vulnerability, equity and protection (Skjelbaek, 34). In proposing the concept, Reardon urges the policy makers to take into consideration the four components as inseparable part of security (Skjelbaek, 34). Third, feminists tries to address the security of women specifically and women need to take part in the fight. By doing this, feminists criticized traditional notions of security because it fails to address women concern. Traditional approach negates the importance of women roles in peace 
and security and also fails to address women as a victims of insecurity because this approach primarily focus on states both as an entity needs for protections and as entity required for protect its citizens.

\section{Conclusion}

The paper has shown that feminists have contributed and played a significant role in political arena particularly in international relations field. They sucessfully contribute their perspective into theoritical framework of state relations, enjoy greater participation in peace and security acitivities and offer new understanding of security as in contrast to the conventional's. The critique of realism conventional notions of security proves that feminists are following the contemporary theoretical debates in International Relations. Feeling realism notion of security is inadequate and neglects the genuine concept of security, feminists articulate alternative visions of security, taking humanistic approach with individual security as the central concern rather than state and military. Furthermore, feminist critiques is one resource for the construction of an analysis of security from a gender and development perspectives. Likewise, feminists propose neutral concept of security to replace male-biased concept such as national security. Doing so, feminists are proposing interdependency; a call for a global cooperation to share common security problems and challenges and a sharing of responsibility.

Over the centuries, feminists are also committed to remove barriers which prevent them from taking part in decision makings. Low representation of women in the decision making bodies and military roles and positions have been believed as factor in which most women's voices unheard and any polices issued fail to mainstream gender perspectives. US, UK and Indonesia, among other countries, can be used as example to show the low representation of women in military as both countries still believe in supremacy of men over women in protecting the states from military threats.

\section{Reference List}

\section{Books}

Ackerly, Brooke A. et al. 2006. Feminist Methodologies for International Relations. Cambridge: Cambridge University Press. 
Blanchard, Eric M. 2003. Gender, International Relations, and the Development of Feminist

Security Theory. Signs Journal of Women and Culture in Society 28(4): 1289-1312

Booth, Ken. 1991."Security and Strategy: Towards a Doctrine for Stable Peace", In Ken Booth (ed). 1991. New Thinking About Strategy and International Security. London: Harper Collins.

Buzan, Barry and Lene Hansen. 2009. The Evolution of International Security Studies. Cambridge: Cambridge University Press.

Buzan, Barry. et al. 1998. Security: A New Framework for Analysis. London: Lynne Rienner Publishers, Inc.

Buzan, Barry. 1983. People, States, and Fear: The National Security Problem in International Relations. (2nd edition). Brighton, Sussex: Wheatsheaf Books LTD.

Connell, R. W. 1995. Masculinities (1st ed). Berkeley: University of California Press.

2005. Masculinities. (2nd ed). Berkeley: University of California Press.

Enloe, Cynthia. 2004. The Curious Feminist: Searching for Women in a New Age of Empire. Berkeley: University of California Press.

Feminist Institute of the Heinrich Ball Foundation. 2006. Peace And Security For All: Feminist Critique Of The Current Peace And Security Policy, Discussion paper May 2006: 1-69.

Jones, Adam. 1996. Does 'Gender' Make The World Go Round? Feminist Critiques Of International Relations. Review of International Studies 22 (1): 405-430.

Kolodziej, Edward A. 2005. Security and International Relations. Cambridge: Cambridge University Press.

McNamara, Robert S. 1968. The Essence of Security. New York: Harper \& Row.

Neocleos, Mark. 2006. From Social to National Security: On the Fabrication of Economic Order. Security Dialogue 37 (3): 363-384.

Parawansa, Khofifah Indar. "Institution Building: An Effort to Improve Indonesian Women's Role and Status." In Robinson, Kathryn, and Sharo Bessell (eds). 2002. Women in Indonesia:Gender, Equity and Development. Pasir Panjang Singapore: Institute of Southeast Asian Studies.

Peou, Sorpong. 2010. Peace and Security in the Asia-Pacific: Theory and Pratice. Santa Barbara, California: Praeger.

Rosati, Jerel A and James M. Scott. 2011. The Politics of United States Foreign Policy (5th ed). Boston:Wadsworth Cengage Learning.

Skjelbaek, Inger. t.t. Gendered Battlefields: A Gender Analysis of Peace and Conflict. PRIO Report 6/97 : 7-53. 
Shapcott, Richard. "Critical Theory", In Christian Reus-Smit and Duncan Snidal (eds). 2010. Oxford Handbook of Internationals Relations. Oxford: Oxford University Press.

Steans, Jill. 1998. Gender and International Relations: An Introduction. Cambridge: Blackwell Publishers.

Stean, Jill. 2010. An Introduction to International Relations Theory: Perspectives and Themes (3rd ed). Essex: Pearson.

Sylvester, Christine. 2004. Feminist International Relations. Cambridge: Cambridge University Press.

Terrif, Terry et al. 1999. Security Studies Today. Massachusetts: Blackwell Publishers Inc.

Tickner, Ann J, 2001. Gendering World Politics: Issues and Approaches in the Post-Cold War Era. New York: Columbia University Press.

Tickner, J Ann and Sjoberg, Laura, "Feminism", in Dunne, Tim et al (eds). 2010. International Relations Theories: Dicipline and Diversity. (2nd). Oxford: Oxford University Press.

True, Jacqui, 2005. "Feminism" in Burchill, Scott, Theories of International Relations (3rd ed). Hampshire: Palgrave Macmillan.

Via, Sandra. 2010, "Gender, Militarism, and Globalization: Soldier for Hire and Masculinity", in Sjoberg, L. and Sandra Via (eds). 2010. Gender, War, and Militarism: Feminist Perspectives. Santa Barbara: Praeger.

Weinstein, Laurie \& Christie C. (eds). 1997. White, Wives and Wives and Warriors: Women and the Military in the United States and Canada. Westport: Greenwood Publishing Group.

Williams, P.D. 2008. "Security Studies: An Introduction", In Williams, P. (ed.), 2008. Security Studies: An Introduction. Abingdon, Oxon: Routledge.

Whitworth, Sandra. 2008." Feminist Perspectives", in Williams, P. (ed.), 2008. Security Studies: An Introduction. Abingdon, Oxon: Routledge.

\section{Online Journal}

Connel, R.W. \& Messerschmidt, James W, Hegemonic Masculinity: Rethinking the Concept [online] available at http://www.engagemenme.org/sites/default/files/Hegemonic\%2oMasculinity\%20Rethinking\%20the\%20Concept\%20(R.\%20W.\%20Connell\%20 and\%20James\%20W.\%20Messerschmidt).pdf [accessed on 10 November 2013].

Murnane, Linda S, 2007. "Legal Impediments To Service: Women in the Military and the Rule of Law". Duke Journal of Gender Law and Policy, 14 :1061. 
http://www.law.duke.edu/shell/cite.pl?14+Duke+J.+Gender+L.+\& + Pol'y+1061\#H1N3 [accessed on 13 January 201]

Rothschild, Emma, "What is Security", American Academy of Arts and Sciences. 124 (3). The Quest for World Order (Summer, 1995), pp. 53-98. [online] http://www.peacepalacelibrary.nl/ebooks/files/Rothschild_What is security.pdf [accessed on 2 January 2014]

\section{Online Report}

Burrelli, David F, 2013.Women in Combat: Issues for Congress. Congresional Research Service https://www.fas.org/sgp/crs/natsec/R42075.pdf [accessed on 22 February 2014].

European Commission,2008. Women and Men in Decision-Making 2007: Analysis of the Situation and Trends. www.ec.europa.eu/employment_social/publications/2008/ke81081 86_en.pdf [Accessed on 3 March 2014].

Inter Parliament Union. 2012. Women in Parliament in 2012: The Year in Perpective. [online]

http://www.ipu.org/pdf/publications/WIP2012e.pdf [accessed on 2 March 2014].

Komnas HAM Perempuan, Siaran Pers Kampanye 16 Hari Anti Kekerasan terhadap Perempuan (25 November-10 Desember 2014). [Online] http://www.komnasperempuan.or.id/2014/11/siaranpers-kampanye-16-hari-anti-kekerasan-terhadap-perempuan-25november-10-desember-2014/ [ accessed on 24 October 2013].

World Economic Forum, The Global Gender Gap Report 2013. [online] http://www3.weforum.org/docs/WEF_GenderGap_Report_2013.p df [accessed on 1 February 2014].

UNDP Human Development Report 2007/8, Available at http://hdrstats.undp.org/indicators/indicators_table.cfm [accessed on 6 november 2013].

UN Secretary-General's report to the Security Council on women, peace and security. Available at http://www.un.org/ga/search/view_doc.asp?symbol=S/2011/598 [accessed on 10 December 2014]

The National Security Strategy: Transform America's National Security Institutions To Meet The Challenges and

Opportunities of the $21^{\text {st }}$ Century. http://20012009.state.gov/r/pa/ei/wh/15430.htm [Accessed on 8 October 2013

The National Security Strategy of the United States of America. 2002. [online] http://www.state.gov/documents/organization/63562.pdf . [Accessed on 9 October 2013] 
The National Security Strategy of the United States of America. 2006. [online] http://nssarchive.us/NSSR/2006.pdf [Accessed on 9 October 2013]

\section{Online Article}

Department of Defence Press Release,[online] http://www.defense.gov/Releases/Release.aspx?ReleaseID=15784 [Accssed on 20 February 2013].

Kementrian Pertahanan dan Keamanan, Kemhan-Kementerian Pemberdayaan Perempuan MOU Pembangunan Pertahanan [online] http://www.kemhan.go.id/kemhan/?pg=31\&id=666 [accessed on 22 February 2013].

Jakarta Globe, Female Officer Fight Bias in Indonesia Military to Claim High Rank http://thejakartaglobe.beritasatu.com/archive/female-officerfights-bias-in-indonesian-military-to-claim-high-rank/. [Accessed on 23 October 2014].

Sommers, Jack, British Army Ex-Commander Says Women Dont Have 'Warrior Ethos' To Serve On Frontline. The Huffington Post [online] http://www.huffingtonpost.co.uk/2014/11/19/women-ukmilitary_n_6183568.html [Accessed on 9 December 2014]

Women in the US Army, http://www.army.mil/women/newera.html [Accessed on 3 October 2013].

Washington Times, 2005. Despite Pressure, Bush Vows 'no women in combat. http://www.washtimes.com/news/2005/jan/11/20050111-1010055277r/. [Accessed 9 October 2013]. 